\title{
Lobation and bronchopulmonary segmentation of Callithrix jacchus (Linnaeus, 1758)
}

\author{
Brunna Muniz Rodrigues Falcãol (D), Ana Karoline Rocha Vieiral ${ }^{1}$,Joyce Galvão de Souza ${ }^{l}$, \\ Artur da Nóbrega Carreirol, Débora Vitória Fernandes de Araújol ${ }^{1}$, José Rômulo Soares dos Santos², \\ Danilo José Ayres de Menezes ${ }^{3}$ \& Gildenor Xavier Medeiros ${ }^{{ }^{*}}$ \\ ${ }^{1}$ Universidade Federal de Campina Grande - UAMV, Avenida Universitária, Patos, PB 58708-110, Brasil \\ ${ }^{2}$ Universidade Federal da Paraíba, Areia, PB, Brasil \\ ${ }^{3}$ Universidade Federal do Rio Grande do Norte, Natal, RN, Brasil \\ *Corresponding author: Gildenor Xavier Medeiros, e-mail: gildenorxavier@gmail.com
}

FALCÃO, B. M. R., VIEIRA, A. K. R., SOUZA, J. G., CARREIRO, A. N., ARAÚJO, D. V. F., SANTOS, J. R. S., MENEZES, D. J. A., MEDEIROS, G. X. Lobation and bronchopulmonary segmentation of Callithrix jacchus (Linnaeus, 1758). Biota Neotropica. 18(2): e20170451. http://dx.doi.org/ 10.1590/1676-0611-BN-2017-0451

\begin{abstract}
The common marmoset (Callithrix jacchus) are small primates belonging to the family Cebidae, subfamily Callitrichinae and are the most well-known and common in adaptation to captivity. The scarcity of data in the literature on the anatomy of these marmosets and wild animals hinders the application of appropriate anesthetic and surgical procedures and therapeutics. In order to understand the anatomic variations in the lobation and bronchopulmonary segmentation the lungs were dissected from nine adult common marmoset (Callithrix jacchus) corpses, five males and four females. In the marmosets, the right lung presented cranial lobe, middle lobe, caudal lobe and accessory lobe while the left lung presented cranial and caudal lobes. The fissures were very pro-eminent in both the lungs. The main right bronchus emitted independent branches, one for each lobe, and it followed in a straight line in the caudal lobe as a continuation of this bronchus and the same was observed in the main left bronchus. The bronchopulmonary segmentation in the right lung ranged from one to five branches in the cranial lobe; the middle lobe had a single branch; the caudal lobe had three to five branches and the accessory lobe had three branches. In the left lung the cranial lobe bronchopulmonary segmentation ranged from one to five branches while in the caudal lobe it was three to four branches.
\end{abstract}

Keywords: Anatomy; bronchial tree; common marmoset; primates

\section{Lobação e segmentação broncopulmonar de Callithrix jacchus (Linnaeus, 1758)}

Resumo: Os saguis-de-tufos-brancos (Callithrix jacchus) são pequenos primatas que pertencem à família Cebidae, subfamília Callitrichinae e são os mais conhecidos e comuns na adaptação ao cativeiro. A escassez de dados disponíveis na literatura sobre a anatomia desses saguis e de animais silvestres dificulta a aplicação de procedimentos anestésicos, cirúrgicos e terapêuticos apropriados. Visando conhecer as variações anatômicas da lobação e segmentação broncopulmonar foram dissecados os pulmões de nove cadáveres de saguis-de-tufos-brancos (Callithrix jacchus) adultos, sendo cinco machos e quatro fêmeas. Nos saguis, o pulmão direito apresentou lobo cranial; lobo médio; lobo caudal e lobo acessório; e o pulmão esquerdo os lobos cranial e caudal. As fissuras são bem proeminentes em ambos os pulmões. O brônquio principal direito emitiu ramos independentes, um para cada lobo, sendo que no lobo caudal seguiu em linha reta como a continuação deste brônquio e o mesmo foi observado no brônquio principal esquerdo. Em relação à segmentação broncopulmonar, o pulmão direito apresentou no lobo cranial variando de um a cinco ramos; lobo médio com um único ramo; o lobo caudal com três a cinco ramos e o acessório com três ramos. No pulmão esquerdo o lobo cranial teve uma variação de um a cinco e no caudal foi de três a quatro ramos.

Palavras-chave: Anatomia, árvore bronquial, sagui-de-tufos-brancos, primatas.

\section{Introduction}

The small anthropoid primates known as the common marmoset (Callithrix jacchus) (Linnaeus 1758) belong to the family Cebidae, subfamília Callitrichinae (Groves et al. 2005) and according to Rylands (2012) the marmosets belong to the order Primates and the family Callitrichidae, and are the most known and common in adaptation to captivity. They are small sized animals with striped fur on the ears, a white spot on the frontal region of the head and general pale gray body coloring. The body is smaller than the tail that serves to ensure the animal's balance. They normally feed on fruit, flowers, seeds, gum tree exudates, insects and spiders, and can also feed on bird eggs and small vertebrates, such as fledglings (Coimbra-Filho et al. 1980).

According to Groves et al. (2005), the common marmoset is native to the north-east of Brazil, but is also found in the south-east and south of the country. The marmosets that occur in the Atlantic rainforest were 
all considered as subspecies of Callithrix jacchus. However, all these taxa, according to Coimbra-Filho (1984) and Ruiz-Miranda et al. (2000), came to be considered as separate species, with Callithrix jacchus referring only to the populations that occur in the Brazilian North East and Caatinga (tropical thorn forest), and that are native to the states of Alagoas, Pernambuco, Sergipe, Paraíba, Rio Grande do Norte, Ceará, Maranhão, Bahia and Tocantins, to the south of the river São Francisco. This species has been introduced to various regions of the country, for example the state of Rio de Janeiro and south-eastern Brazil.

The common marmoset has a non-prehensile tail, longer than its body length, to guarantee balance. They are arboreal, can inhabit various plant physiognomies and are highly adapted to the jumping life. They occur in the Caatinga and the the north-eastern Atlantic rainforest, and have now been dispersed through a vast area as far as the south of the country by anthropic introduction (Stevenson \& Rylands 1988, Pissinatti et al. 2010).

According to Machin (2007), wild animals in a captivity situation for research or rearing purposes should have adequate management so that they are maintained without pain, anxiety or suffering, because animals suffer deleterious effects if pain is not treated, that can result in behavioral changes, weight loss, muscle lesions, depression of the respiratory function, increase in blood pressure, self-mutilation and potential to develop states of chronic pain.

Pissinatti et al. (2010) emphasized that although the marmoset is a good model, its use for scientific purposes in Brazil is restricted. However, in other countries the use of this species, especially for molecular and cytogenetic studies, has favored problem solution and modified the primate systematics, always fitting their classification closer to genetics (Tardif et al. 2008).

According to Renctas (2001), wild animal trafficking, which includes flora, fauna and their products and byproducts, is considered the third biggest illegal activity in the world, following armaments and drugs. Nobody knows the exact size of this trade, but is estimated that the annual turnover is \$10-\$20 billion throughout the world. Rocha (1995) and Lopes (2000) estimated that $5 \%$ to $15 \%$ of this total occurs in Brazil and $95 \%$ of the animals commercialized in the New World are species that occur in Brazil.

Renctas (2001) stated that wild animal trafficking is one of the factors responsible for the introduction of exotic species in Brazil and the world, and in Brazil most of the animals commercialized illegally are from the Northern, North Eastern and Central Western regions. They are transported to the Southern and South-eastern regions on the federal highways.

König \& Liebich (2016) described the respiratory apparatus as essential for gas exchange between air and blood. Thus respiration consists of gas transport to the cells. The respiratory apparatus can be divided into respiratory pathways and gas exchange locations, and the respiratory pathways consist of the following organs: external nose, nasal cavity, nasal portion of the pharynges, larynges, trachea, bronchi and lungs. The gas exchange locations are the respiratory bronchioles, aveolar ducts and alveoli that are inside the lungs.

The respiratory apparatus places the animals in direct relation with the environment and together with the circulatory system adapts to carry out gas exchanges quickly, due to increase in the animal body mass, especially the vertebrates. Thus, the respiratory apparatus is one of the most commonly described in publications that report diseases, pathological lesions and/or clinical treatment in nonhuman primates throughout the world (Lowenstine \& Osborn 2012). The respiratory apparatus has great physiological importance, and its parameters can change, mainly when the animal develops flight activities because of predatory action (Romer \& Pearson 1986); but it is important also in the heat regulation process, endogenous substance metabolism and in protecting the animal against dust, gases and inhaled infectious agents (Cunningham 2014).

The lung anatomy of domestic animals has been well described in all its aspects (Hare 1986, Dyce et al. 2010, König \& Liebich 2016). In wild mammals there are detailed descriptions of the lung anatomy of some species such as: the Paraguayan hairy dwarf porcupine (Sphiggurus villosus) (Guimarães et al. 2012), coati (Nasua nasua) (Oliveira et al. 2012), agouti (Dasyprocta sp) (Peno et al. 2005), jaguarundi (Herpailurus yagouaroundi) (Santos et al. 2011), fox (Cerdocyon thous) (Dantas et al. 2014), Arctic fox (Alopex lagopus) (Voyevoda et al. 1992), lion (Panthera leo) (Nakakuki 1985) and baboon (Papio anubis) (Maina 1987).

The objective of the present study is to know the anatomic variations in the lobation and bronchopulmonary segmentation of the common marmoset (Callithrix jacchus), providing a database for new research, improved surgical techniques and as an aid in preventive medicine.

\section{Material and Methods}

The study was carried out in the Veterinary Anatomy Laboratory (LAV), of the Veterinary Medicine Academic Unit at the Rural Health and Technology Center (CSTR), at the Federal University of Campina Grande (UFCG), Campus de Patos, PB, Brazil.

Lungs were used to carry out this study collected from nine common marmoset corpses used in another study authorized by the SISBIO/ICMbio, protocol $N^{\circ} 44489-1$. All the animals were adult, four females and five males, and were donated to the Wild Animals Screening Center (CETAS) and the Brazilian Institute for the Environment and Renewable Natural Resources (IBAMA) located in the municipality of Cabedelo, Paraíba, for the CSTR LAV at the UFCG. The project of this study was submitted to the Committee of Ethics in Research on use of Animals (CEUA) do CSTR/UFCG, protocol certificate number N ${ }^{\circ}$ CEUA 277/2015.

The lungs were fixed and preserved in $10 \%$ formaldehyde solution. After making a detailed description of the external anatomy, each lung was sectioned and the pulmonary parenchyma was removed carefully, using dissection tweezers and a circular cold light magnifying glass. After this, the heart was carefully removed and the trachea and the lungs were preserved. The lungs were washed externally and internally with water inserted through the trachea. Shortly afterwards a needle was placed in the trachea lumen and tied with string in the attachment location to guarantee the firmness of the needle.

The preparation of the vinyl acetate, following methodology proposed by Rodrigues et al. (1999), began by weighing 13 g powdered vinyl acetate and five g oil paint; $100 \mathrm{~mL} 100 \%$ acetone was measured in a test tube. Next the mixture was homogenized in an Erlenmeyer-type recipient with a glass stick, and then carefully sealed and kept in a refrigerator to be used the next day. When the vinyl acetate was ready, it was shaken well and stained with synthetic red varnish and mixed until it presented a certain viscosity. After preparing the solution, it was inserted into the lung via the trachea with a $3 \mathrm{~mL}$ syringe until the lung lobe were completely filled; the needle was removed and the opening in the trachea was closed by tying the string. Afterwards, the lungs were kept submerged in water for 24 hours to help the solution to solidify.

After this proves process, one lung was separated and placed in a glass recipient where it was submersed in $30 \%$ chloridric acid for eight hours. The lung was washed to remove any tissue remains and thus all the bronchial tree was shown. This was preserved in an individual recipient for long term maintenance of the structure, due to the increased protection.

The other eight lungs were dissected using dissection pincers, with $14 \mathrm{~cm}$ Castroviejo curved scissors and a stereoscopic magnifying glass that was also used to identify each segment of the bronchial system. The results obtained were documented with a digital photographic camera (NIKON ${ }^{\circledR}$ D5100 16.2 megapixel and NIKON ${ }^{\circledR}$ AF-S DX NIKKOR 18-55 mm f/3.5-5.6 G VR lenses). The nomenclature used in the present research followed the Nomina Anatomica Veterinaria (I.C.V.G.A.N \& W.A.V.A 2012). 


\section{Results}

The lungs of the common marmoset are semi-conical in shape, with an oblique surface and apex, base, lateral surface (costal), medial surface (mediastinum), caudal surface (diaphragmatic), dorsal border, ventral border and basal border that are similar to other mammals. The pulmonary hilum was identified on the mediastinum surface, which penetrates the lung root formed by the main bronchi, blood and lymphatic vessels and nerves.

The pulmonary lobation is also similar to that of mammals, the right lung has cranial lobe, middle lobe, caudal lobe and accessory lobe, while the left lung consists of the cranial and caudal lobes (Table 1). However, there was no division in the cranial lobe.

Regarding the fissures, the cranial interlobar fissure was identified in the right lung, that separated the cranial and middle lobes; the caudal inter-lobar fissures that divided the caudal lobe of the cranial and middle lobes and the parasagittal fissure separating the caudal and accessory lobes. In the left lung a single interlobar fissure was observed that divided the caudal lobe from the cranial lobe. These fissures extended from the dorsal margin to the ventral margin completely dividing the lobe in both the lungs (Figure 1).

There was anatomic variation in the lungs of one of the marmosets studied in which the pulmonary fissures were not completely separated in the right and left lungs. In addition, this animal presented an accessory lobe in the left lung.

In the marmoset, the trachea divides into the main right and left dorsal bronchi at the base of the heart. The main right bronchus emitted three independent lobar branches for the cranial, middle and accessory lobes, respectively. For the caudal lobe, the main bronchus followed in a straight line in the interior of the lung, where it becomes known as the caudal lobar bronchus. Two lobar branches emerged from the main left bronchus, one to the cranial lobe and the other to the caudal lobe. As described for the right caudal lobe, the main left bronchus followed a straight line to form the left lobe bronchus.

The right cranial lobar bronchus emitted three to five segmentary bronchi, the middle lobar bronchus emitted only one segmentary bronchus and the caudal lobar bronchus emitted three to four branches, except in one marmoset that presented five segments. A variation of one to three segments was observed in the accessory lobe bronchus, in which one segment predominated in $55.5 \%$ of the cases. The left cranial lobar bronchus of the marmoset presented mostly three to four segments in $66.6 \%$ of the cases, but three lungs presented one, four and five segments. The left caudal lobar bronchus of the marmoset emitted three to four branches, with a higher incidence of four segments, totaling $66.6 \%$ of the cases (Figure 2).

Table 1. Lobation of lungs the domestics and wild animals.

\begin{tabular}{|c|c|c|c|}
\hline \multirow{2}{*}{ ESPECIE } & \multicolumn{2}{|c|}{ LOBATION } & \multirow{2}{*}{ REFERENCE } \\
\hline & RIGHT LUNG & LEFT LUNG & \\
\hline $\begin{array}{l}\text { Common marmoset } \\
\text { (Callithrix jacchus) }\end{array}$ & $\begin{array}{l}\text { Cranial lobe, middle lobe, caudal lobe and accessory } \\
\text { lobe }\end{array}$ & Cranial lobe and caudal lobe & \\
\hline $\begin{array}{l}\text { Crab-eating raccoon } \\
\text { (Procyon cancrivorus) }\end{array}$ & $\begin{array}{l}\text { Cranial lobe, middle lobe, caudal lobe and accessory } \\
\text { lobe }\end{array}$ & Cranial lobe and caudal lobe & $\begin{array}{l}\text { Sestari et al., 2011; } \\
\text { Santos et al., } 2013 \text {. }\end{array}$ \\
\hline $\begin{array}{l}\text { Hairy dwarf porcupine } \\
\text { (Sphiggurus villosus) }\end{array}$ & $\begin{array}{l}\text { Cranial lobe, middle lobe, caudal lobe and accessory } \\
\text { lobe }\end{array}$ & $\begin{array}{l}\text { Cranial lobe (cranial part and caudal part) and } \\
\text { caudal lobe }\end{array}$ & Guimarães et al., 2012 \\
\hline $\begin{array}{l}\text { Fox } \\
\text { (Cerdocyon thous) }\end{array}$ & $\begin{array}{l}\text { Cranial lobe, middle lobe, caudal lobe and accessory } \\
\text { lobe }\end{array}$ & $\begin{array}{l}\text { Cranial lobe (cranial part and caudal part) and } \\
\text { caudal lobe }\end{array}$ & Dantas et al., 2014 \\
\hline Dogs, cats and suines & $\begin{array}{l}\text { Cranial lobe, middle lobe, caudal lobe and accessory } \\
\text { lobe }\end{array}$ & $\begin{array}{l}\text { Cranial lobe (cranial part and caudal part) and } \\
\text { caudal lobe }\end{array}$ & Dyce; Sack; Wensing, 2010 \\
\hline Ruminants & $\begin{array}{l}\text { Cranial lobe (cranial part and caudal part), } \\
\text { middle lobe, caudal lobe and accessory lobe }\end{array}$ & $\begin{array}{l}\text { Cranial lobe (cranial part and caudal part) and } \\
\text { caudal lobe }\end{array}$ & Dyce; Sack; Wensing, 2010 \\
\hline Equines & Cranial lobe, caudal lobe and accessory lobe & Cranial lobe and caudal lobe & Dyce; Sack; Wensing, 2010 \\
\hline
\end{tabular}
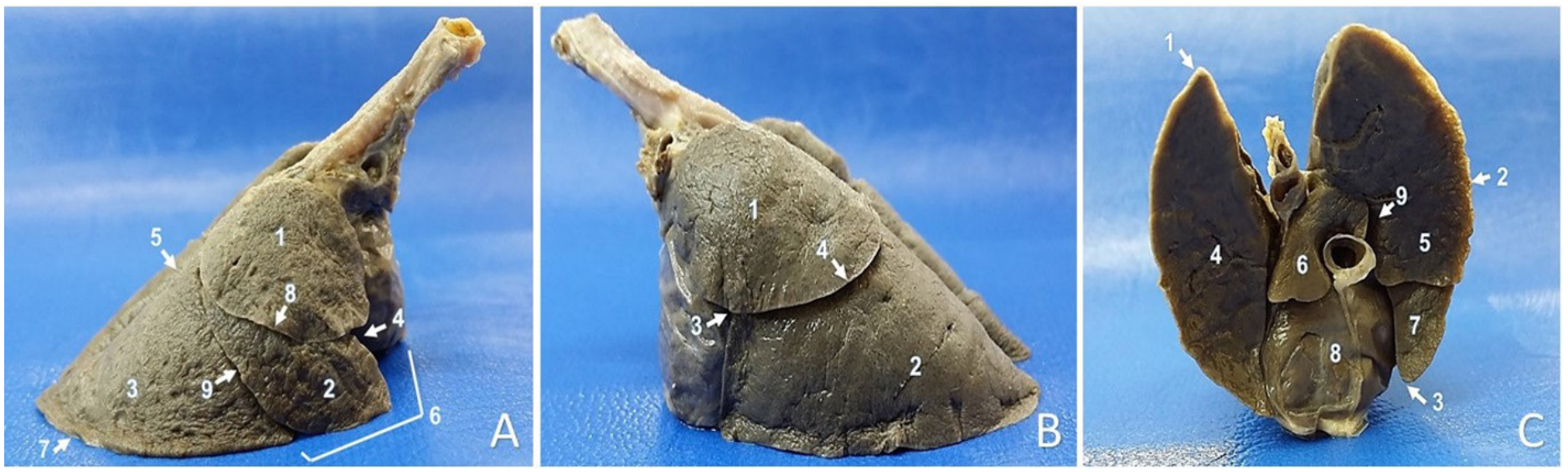

Figure 1. A - Lateral view of the right lung of common marmoset. 1 Cranial lobe, 2 Middle lobe, 3 Caudal lobe, 4 Heart incisura, 5 Dorsal margin, 6 Ventral margin, 7 Basal margin, 8 Cranial interlobar fissure, 9 Caudal interlobar fissure. B - Lateral view of left lung of common marmoset. 1 Cranial lobe, 2 Caudal lobe, 3 Heart incisura, 4 Interlobar fissure. C - Caudal view of lung of marmoset. 1 Dorsal margin, 2 Basal margin, 3 Ventral margin, 4 Left caudal lobe, 5 Right caudal lobe, 6 Accessory lobe, 7 Middle lobe, 8 Heart, 9 Parassagital fissure. 

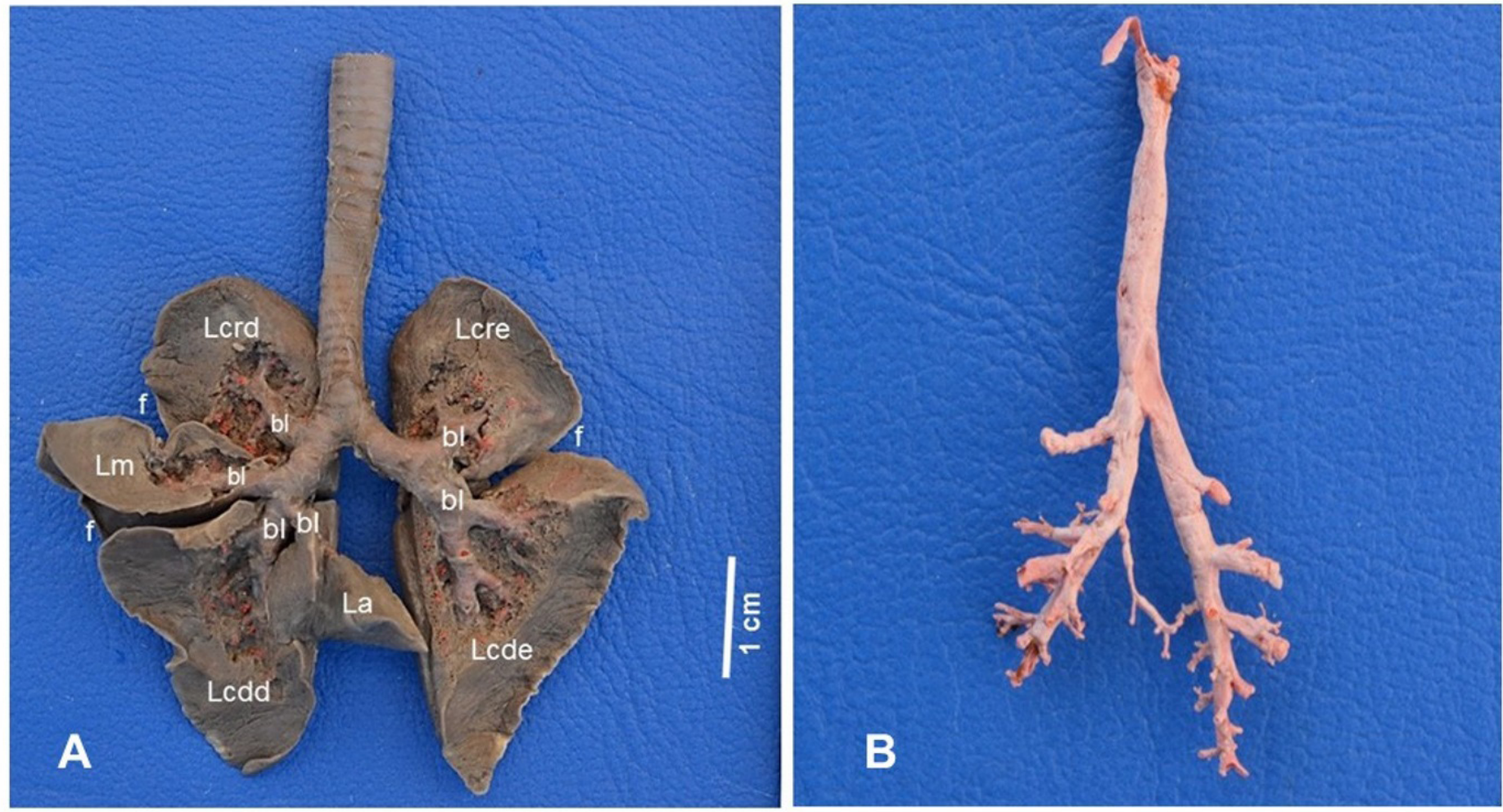

Figure 2. Ventral view of lung of common marmoset. A - lobes separate per fissure (f); right cranial lobe (Lcrd), middle lobe (Lm), right caudal lobe (Lcdd) and accessory lobe (La); left cranial lobe (Lcre), left caudal lobe (Lcde) and lobular bronchi (bl). B - The tracheobronchial tree witch lobular and segmental bronchis

\section{Discussion}

The non-existence of division in the cranial lobe of the common marmoset in the present study differed from findings for other domestic animals such as dogs, sheep, cattle and pigs (Dyce et al. 2010) and wild animals such as the fox (Cerdocyon thous) (Dantas et al. 2014), lion (Panthera leo) (Nakakuki 1985), Artic Fox (Alopex lagopus) (Voyevoda et al. 1992) and Paraguayan hairy dwarf porcupine (Sphiggurus villosus) (Guimarães et al. 2012). Similalrity was observed in the common marmoset and the crab-eating raccoon (Procyon cancrivorus, Cuvier, 1798) (Sestari et al. 2011) and domestic equine species (Dyce et al. 2010) that also do not have the cranial lobe divided into cranial and caudal portions.

The fissures observed in the right and left lobes of the specimens were similar to those described in the lungs of the Paraguayan hairy dwarf porcupine (Sphiggurus villosus) (Guimarães et al. 2012), domestic carnivores (Hare 1986), crab-eating raccoon (Procyon cancrivorus, Cuvier 1798) (Sestari et al. 2011) and agouti (Dasyprocta sp.) (Penno et al. 2005). The lung of the marmoset presented a concavity, the heart incisura, similar to other mammals.

The presence of an accessory lobe in the left lung in the specimen differed from the others was similar to that described by Rehder et al. (2008) in lungs of pacas (Agouti paca). The ramification of the right cranial lobar bronchus is similar to that described by Voyevoda et al. (1992) in the dog and the Artic fox (Alopex lagopus) and by Liebich (1974) and Nakakuki (1983) in rats (Rattus norvegicus). Dantas et al. (2014) demonstrated that the fox (Cerdocyon thous) has eight to 10 segments, the lion (Panthera leo) (Nakakuki 1985) has six segments and in the lung of the Paraguayan hairy dwarf porcupine (Sphiggurus villosus) there were five segments for the cranial part and three for the caudal part (Guimarães et al. 2012). In all the mammal species studied there was little variation in the quantity of segmentary bronchi emitted from the right cranial lobar bronchus except in the agouti (Dasyprocta sp.), that has from two to 12 segmentary bronchi (Penno et al. 2005).

The middle lobar bronchus was similar to that observed by Voyevoda et al. (1992) in the dog and arctic fox (Alopex lagopus). But the marmoset differs from the fox (Cerdocyon thous) (Dantas et al. 2014) and the lion (Panthera leo) (Nakakuki 1985) that have an average of 10 segments, as does the rat (Rattus norvegicus) (Liebich 1974, Nakakuki 1983) that presented a variation of eight to 10 segments, the Paraguayan hairy dwarf porcupine (Sphiggurus villosus) (Guimarães et al. 2012) has four segments and the agouti (Dasyprocta sp.) (Penno et al. 2005) has six to 10 segments.

The presence of three to four branches from the caudal lobar bronchus is similar to the fox (Cerdocyon thous) (Dantas et al. 2014) and the dog (Canis lupusf. familiars) (Voyevoda et al. 1992). The other mammals were shown to be different from the marmoset studied here, in which the rat lung (Rattus norvegicus) (Liebich 1974, Nakakuki 1983) and the lion lung (Panthera leo) (Nakakuki 1985) had 13 segments; that of the Paraguayan hairy dwarf porcupine (Sphiggurus villosus) (Guimarães et al. 2012), had 11 segmentary bronchi and that of the Arctic foxes (Alopex lagopus) (Voyevoda et al. 1992), had seven segments and that of the jaguarandi (Herpailurus yagouaroundi- Severtzow, 1848) (Santos et al. 2011) had six segments.

The branching of this accessory lobe bronchus with predominantly one segment is similar to that of the lion (Panthera leo), described by Nakakuki (1985) and the agouti (Dasyprocta sp.) (Penno et al. 2005, Santos et al. 2011) and the jaguarandi (Voyevoda et al. 1992). Dantas et al. (2014) described a variation of three to five segments, but most of the cases were had four segments. Liebich (1974) and Nakakuki (1983) found three branches in the rat (Rattus norvegicus), a higher number than that of the marmoset. 
When studying the segments of the left cranial lobar bronchus, it was observed that the marmoset differs from other species, regarding the external anatomic part because there is no division between the cranial and caudal parts, but is similar regarding the total number of segments to dogs and arctic foxes (Alopex lagopus) (Voyevoda et al. 1992), with four segments and also to the agouti (Dasyprocta sp.) (Penno et al. 2005) that emitted five to seven segments. However, the marmoset presented a much smaller number compared to the fox (Cerdocyon thous) (Dantas et al. 2014), that has a mean of 10 to 13 branches in the cranial part and seven to 13 branches in the caudal part. The marmoset lung also differed from that of the lion (Panthera leo) (Nakakuki 1985), where the cranial and caudal portions of the cranial lobe presented eight and seven segments, respectively Guimarães et al. (2012) described seven segments in the Paraguayan hairy dwarf porcupine (Sphiggurus villosus), five for the cranial part and two for the caudal part, showing significant differences in relation to the marmoset in the present study.

Comparison of the left caudal lobar bronchus branching with that of other species shows that the species closest to the marmoset were the jaguarandi (Herpailurus yagouaroundi- Severtzow, 1848) (Santos et al. 2011) and the dog (Voyevoda et al. 1992), both with five segments. The lion (Panthera leo) (Nakakuki 1985), the Paraguayan hairy dwarf porcupine (Sphiggurus villosus) (Guimarães et al. 2012) and the fox (Cerdocyon thous) (Dantas et al. 2014) showed a variation of between 10 and 13 segments. In rats (Rattus norvegicus), a large quantity of segmentary bronchi was observed (from 14 to 16) branching from the caudal lobar bronchus Nakakuki (1983) and Liebich (1974).

The results obtained showed that the bronchopulmonary lobation and segmentation of the common marmoset (Callithrix jacchus) consists of lobes and numbers of segmentary bronchi similar to other mammals, with small variations. The segmentation varied little among the specimens, but this knowledge is relevant for better diagnosis of lung lesions and for surgical and anesthetic procedures.

\section{Author Contributions}

Brunna Muniz Rodrigues Falcão - Contribution to data collection, to data analysis and interpretation and to manuscript preparation;

Ana Karoline Rocha Vieira - Contribution to manuscript preparation; Joyce Galvão de Souza - Contribution to data analysis and interpretation; Artur da Nóbrega Carreiro - Contribution to data analysis and interpretation;

Débora Vitória Fernandes de Araújo - Contribution to data collection; José Rômulo Soares dos Santos - Substantial contribution in the concept and design of the study;

Danilo José Ayres de Menezes - Contribution to critical revision, adding intelectual content;

Gildenor Xavier Medeiros - Substantial contribution in the concept, design of the study and to critical revision, adding intelectual content.

\section{Conflicts of Interest}

The authors declares that they have no conflict of interest related to the publication of this manuscript.

\section{References}

COIMBRA-FILHO, A.F., ROCHA, N.D.C.\& PISSINATTI, A. 1980. Morfofisiologia do ceco e sua correlação com o tipo odontológico em Callitrichidae (Platyrrhini, Primates). Rev. Bras. Biol.,40, p.177.

COIMBRA-FILHO, A.F. 1984. Situação atual dos calitriquídeos que ocorrem no Brasil (Callitrichidae - Primates). In: Mello, M.T., A Primatologia no Brasil. Sociedade Brasileira de Primatologia, Brasília, p.15-33.
CUNNIGHAM, J.G. 2014. Tratado de Fisiologia Veterinária. 5 ed. Rio de Janeiro, Guanabara Koogan.

DANTAS, A.K.F.P., SILVA, E.F., NETO, R.B.S., SANTOS, J.R.S., CORDEIRO, J.F., OLIVEIRA, M.F., MEDEIROS, G.X. \& MENEZES, D.J.A. 2014. Morfologia e Segmentação Pulmonar de Raposas (Cedocyon thous). Acta Vet. Bras., 8, p.31-37.

DYCE, K.M., SACK, W.O \& WENSING, C.J.G. 2010. Tratado de Anatomia Veterinária. 4 ed. Rio de Janeiro, Elsevier.

GROVES, C. In: REEDER, D.M. \& WILSON, D.E. 2005. Mammal Species of the World. A Taxonomic and Geographic Reference. 3 ed. Johns Hopkins University Press, p.2000.

GUIMARÃES, G.C., LOPES, G.C., ROSA, M.C.B., SESTARI, C.E.O. \& OLIVEIRA, F.S. 2012. Lobação pulmonar e distribuição brônquica do ouriçocacheiro (Sphiggurus villosus). Acta Sci. Vet., 40, 2, p.1037.

HARE, W.C.D. 1986. Sistema respiratório do carnívoro. In: Getty, R. Anatomia dos Animais Domésticos. 5 ed. Guanabara Koogan, Rio de Janeiro, 2, p.1465-1481.

I.C.V.G.A.N - International Committee on Veterinary Gross Anatomical Nomenclature; W.A.V.A. - World Association of Veterinary Anatomists. Nomina AnatomicaVeterinaria. 2012. Hannover, Columbia, MO, Ghent, Sapporo: Editorial Committee.

KÖNIG, H.E. \& LIEBICH, H.G. 2016. Anatomia dos animais domésticos: texto e atlas colorido. Tradução: Régis Pizzato. 6 ed. Porto Alegre, Artmed, p.377-398.

LIEBICH, H.G. 1974. The Segmentation of the Lung of the white Rat (Rattus norvegicus). Anat. Histol. Embryol. Journal of the World Association of Veterinary Anatomists, 3, p.243-249.

LOPES, J.C. 2000. O Tráfico Ilegal de Animais Silvestres no Brasil.

LOWENSTINE, L.J. \& OSBORN, K.G. 2012. Respiratory system diseases of nonhuman primates. 2 ed. In: ABEE, R.C., MANSFIELD, K., TARDIF, S. \& MORRIS, T. Nonhuman Primates in Biomedical Research. London: Elsevier, 2, p.413-483.

MACHIN, K.L. 1984. Wildlife analgesia. In.: WEST, G., HEARD, D. \& CAULKETT, n. 2007. Zoo animal \& wildlife immobilization and anesthesia. Ames: Blackwell Publishing, p.43-60.

MAINA, J.N. 1987. The morphology and morphometry of the adult normal baboon lung (Papio anubis). J. Anat., 150, p.229-245.

NAKAKUKI, S. 1985. The bronchial tree, lobular division, and blood vessels of the lion lung. Anat. Anz., p.315-321.

NAKAKUKI, S. 1983. Bronchial ramification. In: the bronchial tree and blood vessels of the rat lung. Anat. Anz., p.306-307.

OLIVEIRA, V.C. 2012. Estudo morfológico do sistema respiratório de quati (Nasuanasua). Biotemas, p.81-92.

PENNO, A.K., CARVALHO, M.A.M., ASSIS-NETO, A.C., AZEVEDO, L.M. \& MELLO, G.W.S. 2005. Lobação, ramificação brônquica e distribuição arterial no pulmão da cutia (Dasyprocta sp., Mammalia - Rodentia). Braz. J. Vet. Res. Anim. Sci. São Paulo, 42, 5, p.331-336.

PISSINATTI, A., GOLDSCHMIDT, B. \& SOUZA, I.V. 2010. Taxonomia. In: ANDRADE, A. et al. Biologia, manejo e medicina de primatas não humanos na pesquisa biomédica. Rio de Janeiro, Fiocruz, 2, p.51.

RENCTAS (Rede Nacional de Combate ao Tráfico de Animais Silvestres). 2001. $1^{\circ}$ Relatório Nacional sobre o Tráfico de Fauna Silvestre.

REHDER, A.M.A., CORTELLINI, L.M., OLIVEIRA, F.S. \& MACHADO, M.R.F. 2008. Lobação, árvore brônquica e vascularização arterial do pulmão da paca (Agouti paca, LINNAEUS, 1766). Ciênc. Anim. Bras., 9, 2, p.442-448.

ROCHA, F.M. 1995. Tráfico de Animais Silvestres. WWF. Documento para discussão.

ROMER, A.S. \& PEARSON, T.S. 1986. The Vertebrate Body. 6 ed. Philadelphia, W. B. Saunders, p.679.

RUIZ-MIRANDA, C.R., AFFONSO, A.G., MARTINS, A. \& BECK, B. 2000. Distribuição do sagui (Callithrix jacchus) nas áreas de ocorrência do micoleão-dourado (Leontopithecus rosalia) no estado do Rio de Janeiro. Neotrop. Primates, 8, 3, p.98-101.

RYLANDS, A.B. 2012. Taxonomy of the Neotropical Primates. International Union for Conservation of Nature (IUCN), Species Survival Commission (SSC), Primate Specialist Group, Gland. 
Falcão, B.M.R. et al.

SANTOS, A.L.Q., MORAES, F.M., CARVALHO, S.F.M., MENEZES, L.T., KAMINISHI, A.P.S., LEONARDO, T.G. \& NASCIMENTO, L.R. 2011 Lobos pulmonares e formação dos brônquios do gato mourisco (Herpailurus yagouaroundi- Severtzow, 1848) (Felidae). PUBVET, Londrina, 5, p.13.

SESTARI, C.E.O., CORRÊA, A.F., MARTINS, L.L., GUIMARÃES, G.C. \& OLIVEIRA, F.S. 2011. Lobação pulmonar e distribuição brônquica em mãopelada (Procyon cancrivorus, Cuvier, 1798) - Relato de dois casos. Veterinária e Zootecnia. Arq. Bras. Med. Vet., 18, 3, p.374-378.

STEVENSON, M. \& RYLANDS, A.B. 1988. The marmosets, genus Callithrix. In: MITTERMEIER, R.A., RYLANDS, A.B., COIMBRA-FILHO, A. \& FONSECA, G.A.B. Ecology and behavior of Neotropical primates, W.W.F., Washington, p.131-222.
TARDIF, S.D., ARAÚJO, A., ARRUDA, M.F., FRENCH, J.A., SOUSA, M.B \& YAMAMOTO, M.E. 2008. Reproduction and aging in marmosets and tamarins. In: ATSALIS, S., MARGULIS, S.W. \& HOF, P.R. Interdisciplinary Topics in Gerontology. Karger, 36, p.29-48.

VOYEVODA, T.V, SHISHKIN, G.S., VALITSKAYA, R.I. \& UMANTSEVA, N.D. 1992. Macrostructure differences of polar fox and dog lungs. In: The Anatomical Record. American Association of Anatomists. 234, 1, p.89-92.

Received: 18/09/2017

Revised: 05/02/2018

Accepted: 07/02/2018

Published online: 05/03/2018 